\title{
DIAGNOSTIC VALUE OF CONTRAST-ENHANCED ULTRASOUND EVALUATION OF MALIGNANT AND BENIGN SOLITARY THYROID NODULES
}

\author{
Pēteris Priedītis ${ }_{3}^{1 \#}$, Maija Radziṇa ${ }^{1}$, Ilze Štrumfa ${ }^{2}$, Zenons Narbuts ${ }^{3}$, Arturs Ozoliṇs ${ }^{3}$, \\ Andrejs Vanags ${ }^{3}$, and Jānis Gardovskis ${ }^{3}$ \\ ${ }^{1}$ Department of Radiology, Rīga Stradinš University, Dzirciema iela 16, Rīga, LV-1007, LATVIA; \\ peteris.prieditis@inbox.Iv \\ ${ }^{2}$ Department of Pathology, Rīga Stradinš University, Dzirciema iela 16, Rīga, LV-1007, LATVIA \\ ${ }^{3}$ Department of Surgery, Rīga Stradinš̌ University, Dzirciema iela 16, Rīga, LV-1007, LATVIA \\ \# Corresponding author
}

Contributed by Jānis Gardovskis

\begin{abstract}
The aim of the study was to investigate the diagnostic value of contrast-enhanced ultrasound (CEUS) in differentiating benign and malignant thyroid nodules. Thirty-five patients with morphologically proved thyroid nodules (17 malignant; 18 benign), underwent CEUS examination. Five enhancement patterns were evaluated: vascularisation, homogeneity, presence of peripheral rim type enhancement, wash-out rate of the contrast medium, and enhancement using microvascular imaging application. Time-intensity curves (TIC) were analysed in post-processing and defined as three types: slow versus rapid and stable versus rapid biphasic wash-out. Diagnostic value of the listed CEUS parameters was calculated. The results showed medium strength correlation between morphology (benign versus malignant nodule) and type of TIC curve $r_{\mathrm{s}}=0.38(\mathrm{p}=0.021)$, as well as between mode of contrast enhancement $r_{\mathrm{s}}=0.39(\mathrm{p}=0.022)$ and wash-out pattern $r_{\mathrm{s}}=$ $0.39(\mathrm{p}=0.024)$. The overall pooled sensitivity of selected diagnostic parameters was $82 \%$, specificity $57 \%$, and accuracy $70 \%$. Malignant nodules were characterised by iso- or hypovascular contrast enhancement and slow wash-out, while benign nodules showed hypervascular enhancement with rapid wash-out TIC curve and rim-like pattern. The CEUS patterns significantly differed between malignant and benign thyroid nodules with high diagnostic accuracy. Thus, CEUS has important clinical value as an additional tool to ultrasound and fine needle biopsy.
\end{abstract}

Key words: contrast-enhanced ultrasound, thyroid nodules.

\section{INTRODUCTION}

Thyroid nodules are a common clinical problem. Ultrasonography (US) is used as the modality of choice in diagnostic radiology for patients with suspected thyroid mass lesions. It is a non-invasive, widely available, and inexpensive method and provides relevant information about gross structure of a nodule. If nodules in the thyroid gland are found, the main clinical aim is to exclude malignant tumours, which constitute up to $5 \%$ of all thyroid nodules (Gharib et al., 2010). Several US signs point to the likelihood of malignant growth: marked hypoechogenicity, microcalcifications, spicular or micronodular contour and aspect ratio with height greater than width. However, the specificity and sensitivity of an individual feature is not sufficient for reliable detection of malignant tumours. Combination of features possesses higher diagnostic accuracy, but generally fine needle aspiration biopsy (FNAB) is required to specify the nature of the nodule. Fine needle biopsy must be applied to solid nodules larger than $10 \mathrm{~mm}$ or the ones presenting with at least one sign of malignant behaviour in US examination (Gharib et al., 2010). The cytological assessment of the collected material is descriptive and divided into defined categories by Bethesda (Thy1-6) or British Thyroid Association (Thy1-5) systems (Anonymous, 2007; Cibas et al., 2009). Up to $0.5-25 \%$ of biopsies are non-diagnostic (Thy 1), and about $1-2 \%$ are false negative. The risk of malignant tumour in the case of Bethesda category 3 (unspecified follicular neoplasia) is up to 5-15\% (Cibas et al., 2009). Unfortunately, effectiveness of repeated FNAB does not exceed 50\% (Chow et al., 2001; Orija et al., 2007; Strauss et al., 2008; Samir et al., 2012), thus precluding reliable solution for the diagnostic problem.

To determine the correct treatment tactics and avoid unnecessary surgical procedures, new non-invasive diagnostic 
methods are explored that allow to reliably differentiate between malignant and benign thyroid nodules. A new diagnostic imaging method that has already been successfully used in liver, renal, or pancreatic diseases is contrastenhanced ultrasound (CEUS) evaluation (Piscaglia et al., 2012). Over the last decade, numerous studies have focused on analysis of macro- and micro-vascularisation patterns using ultrasound contrast agents. However, the experience with CEUS in thyroid pathology is scant. Qualitative and quantitative evaluation parameters and criteria used in analysis differ among research groups. The results are ambiguous and sometimes contradictory. The diagnostic value of CEUS has been analysed in only very few studies (Ferrari et al., 2008; Zhang et al., 2010; Nemec et al., 2012; Cantisani et al., 2013; Giusti et al., 2013; Deng et al., 2014; Ma et al., 2014), yielding variable results; the sensitivity varies between 68-100\% and specificity - between $67-594 \%$.

Thus, the objective of our study was to assess the diagnostic accuracy parameters of thyroid CEUS and evaluate the potential of this method to differentiate between malignant and benign thyroid nodules.

\section{MATERIALS AND METHODS}

From April 2014 to May 2015, 650 patients underwent consecutive FNAB. Thirty-five patients with solitary thyroid nodules were enrolled in a prospective study. Seventeen patients with cytologically proved or suspected malignant tumour underwent surgery and malignancy was confirmed histologically. Findings were compared with benign nodules group of 18 patients. Nodules were evaluated as benign if there were no signs of growth, no visible dynamics in follow-up US examinations at least during the last four years and FNAB yielded benign cytological findings. The average age of patients was $49 \pm 14$ (range, 25-72) years; 30 females and 5 males. Exclusion criteria were the following: patients with fully or partially cystic nodules, multinodular goiter, nodules presenting with macrocalcifications, previously operated thyroid gland and repeatedly non-resultative FNAB specimen, as well as patients affected by thyroid cancer metastases in the lymph nodes or in distant organs necessitating referral for ${ }^{131} \mathrm{I}$ therapy. US, FNAB, and CEUS were performed by radiologists with 10 and 30 years-long experience in diagnostic imaging of thyroid. US and CEUS were performed by Philips iU22 ultrasound equipment (Philips Medical Systems, the Netherlands) with high-frequency linear transducers $5-18 \mathrm{MHz}$ for FNAB guidance and 5-12 MHz for CEUS. Contrast medium SonoVue (Bracco, Milan, Italy) was administered into the cubital vein via manual bolus of $1.5 \mathrm{ml}$ through $20 \mathrm{G}$ catheter with following flush of saline $20 \mathrm{ml}$. The examination was done using a low mechanical index (0.7 to 0.8$)$ and up to a $90 \mathrm{~s}$ long cine loop was digitally recorded. During the 70-90th second, manual burst of microbubbles was performed and cumulative enhancement was assessed using Microvascular Imaging (MVI) application. The record anal- ysis was done using the Q-LAB Application (Philips Medical Systems, the Netherlands). Data analysis was performed by two radiologists independently and consensus was reached comparing the results.

Mainly qualitative parameters were selected to characterise patterns of the nodule enhancement: vascularisation compared to the surrounding tissue defined as hyper- versus isoversus hypovascular enhancement; homogeneity (homogeneous versus non-homogeneous); peripheral rim-like contrast enhancement; wash-out rate of the contrast medium compared to the surrounding tissue (rapid versus simultaneous versus late); and enhancement compared to the surrounding tissue using MVI application (hyper- versus isoversus hypo-enhancing versus rim-like enhancing). During the image post-processing, time-intensity curves (TIC) were generated placing the region of interest (ROI) in the nodule occupying the largest possible area of the nodule and in the surrounding tissues. The TIC curve type was defined as slow wash-out versus rapid and stable versus rapid biphasic. In the quantitative analysis of the TIC curve, the following parameters were evaluated: area of ROI $\left(\mathrm{mm}^{2}\right)$, wash-in slope $(\mathrm{dB} / \mathrm{s})$, time to peak (TTP, s), peak intensity $(\mathrm{dB})$, area under the curve (AUC, dB/s), mean transit time (MTT, $\mathrm{s}$ ), and half-time wash-out (s). The diagnostic accuracy indicators were defined for those parameters showing the greatest correlation with the morphological nature of a nodule. As was revealed during the course of the study, these parameters comprised vascularity compared to the surrounding glandular tissue, wash-out upon visual assessment, TIC curve wash-out type and peripheral or rim-like enhancement.

The obtained study data were registered in a work-station using Microsoft Excel 2012. Statistical data analysis was carried out using IBM SPSS software (Version 22.0) and Graph Pad Prism software (Version 6.0). Descriptive statistical methods were used to calculate group distribution, central trend indicator (mean value, median) and distribution indicator (standard deviation, SD) as well as frequency. Conclusive statistical methods were used to compare both groups: hypothesis testing methods, such as group comparison by independent variables methods, applying single factor Analysis of Variance (ANOVA) and Spearman correlation analysis. To obtain the diagnostic test efficacy, the selected values were analysed in comparison to surgery or FNAB results (sensitivity, specificity, accuracy, negative predictive value (NPV), positive predictive value (PPV), likelihood ratio) using receiver operating characteristic curve (ROC) analysis. In addition, 95\% confidence intervals (CI) were calculated. Results were considered statistically significant if the $p$ value was less than 0.05 (Replogle et al., 2009; Ferlay et al., 2013).

This prospective study was approved by the Riga Stradiņ̌̌ University Ethics Committee. All patients were informed about the study process and aim. An informed consent for participation in the study was received. 
For the group of patients who underwent thyroid surgery, morphological analysis of the surgery specimen disclosed primary malignant thyroid tumours in all of the 17 patients. Of these, 12 cases were confirmed as papillary thyroid carcinoma, four cases were follicular type of papillary carcinoma and a single case was papillary microcarcinoma. Qualitative comparative contrast enhancement results in the two morphological groups are displayed in Table 1.

Malignant nodules presented iso-hypovascular contrast enhancement and a slow wash-out type TIC curve (Type 1), while benign nodules showed hypervascular enhancement with rapid wash-out TIC curve and rim-like pattern.

There was moderately strong correlation between the morphological findings (benign versus malignant) and type of TIC curve $\mathrm{r}_{\mathrm{s}}=0.38(p=0.021)$, as well as with mode of contrast enhancement (hypo- versus iso- versus hyper-) $\mathrm{r}_{\mathrm{s}}=$ $0.39(p=0.022)$ and wash-out patterns $\mathrm{r}_{\mathrm{s}}=0.39(p=$ $0.024)$, all with statistical significance.

Four enhancement patterns were selected to detect diagnostic value of CEUS in differentiation between malignant and benign nodules. The diagnostic value of these contrastenhancement patterns is shown in Table 2.

Rim enhancement showed the highest sensitivity and specificity among all patterns and was considered as a specific sign for benign nodules with sensitivity $94 \%$, specificity

Table 1

QUALITATIVE EVALUATION OF CEUS PARAMETERS IN BENIGN AND MALIGNANT THYROID NODULES

\begin{tabular}{lcc|c}
\hline \multicolumn{1}{c}{ Parameters } & Malignant: N (\%) & Benign: N (\%) & $p$ value \\
\hline \multicolumn{4}{c}{ Enhancement of nodule in comparison to the surrounding tissues } \\
\hline Hypoenhancing & $7(41.1)$ & $4(22.2)$ & 0.02 \\
Isoenhancing & $7(41.1)$ & $4(22.2)$ & \\
Hyperenhancing & $3(17.8)$ & $10(55.6)$ & \\
TIC curves & & \\
Type 1 (slow) & $11(64.7)$ & $4(22.2)$ & \\
Type 2 (rapid) & $2(11.8)$ & $5(27.8)$ & \\
Type 3 (biphasic) & $4(23.5)$ & $9(50.0)$ & \\
\hline
\end{tabular}

Contrast wash-out in comparison to the surrounding tissues

\begin{tabular}{lccc}
\hline Rapid & $3(17.6)$ & $8(44.4)$ & 0.029 \\
Simultaneous & $11(64.8)$ & $4(22.2)$ & \\
Late & $3(17.6)$ & $6(33.4)$ & \\
\hline
\end{tabular}

Contrast enhancement homogeneity in comparison to the surrounding tissues

\begin{tabular}{lccc}
\hline Homogeneous & $2(11.8)$ & $7(38.9)$ & 0.08 \\
Heterogeneous & $14(88.2)$ & $11(61.1)$ & $<0.0001$ \\
Rim & $1(5.9)$ & $11(61.1)$ & \\
\hline
\end{tabular}

MVI application enhancement in comparison to the surrounding tissues

\begin{tabular}{lccc}
\hline Hypoenhancing & $4(23.5)$ & $1(5.6)$ & 0.01 \\
Isoenhancing & $3(17.6)$ & $3(16.7)$ & \\
Hyperenhancing & $2(11.8)$ & $10(55.6)$ & \\
\hline Rim & $1(5.9)$ & $11(61.1)$ & $<0.0001$
\end{tabular}

CEUS, contrast-enhanced ultrasound; N, number; TIC, time-intensity curve; MVI, microvascular imaging
DIAGNOSTIC VALUE OF CONTRAST ENHANCEMENT PATTERNS

\begin{tabular}{l|c|c|c|c|c}
\hline \multicolumn{1}{c|}{ Values } & $\begin{array}{c}\text { Rim en- } \\
\text { hancement }\end{array}$ & $\begin{array}{c}\text { Hypo (iso) } \\
\text { vascular }\end{array}$ & $\begin{array}{c}\text { TIC curve } \\
\text { slow } \\
\text { wash-out } \\
\text { (Type 1) }\end{array}$ & $\begin{array}{c}\text { Slow } \\
\text { wash-out } \\
\text { qualitative }\end{array}$ & $\begin{array}{c}\text { Pooled } \\
\text { values }\end{array}$ \\
\hline Sensitivity & 0.94 & 0.82 & 0.73 & 0.82 & 0.82 \\
Specificity & 0.61 & 0.56 & 0.69 & 0.56 & 0.57 \\
Accuracy & 0.77 & 0.69 & 0.71 & 0.69 & 0.72 \\
PPV & 0.70 & 0.64 & 0.73 & 0.64 & 0.68 \\
NPV & 0.92 & 0.77 & 0.69 & 0.77 & 0.79 \\
PosLHR & 2.42 & 1.85 & 2.38 & 1.85 & 2.13 \\
NegLHR & 0.09 & 0.31 & 0.39 & 0.31 & 0.28 \\
Diagnostic OR & 25.14 & 5.83 & 6.18 & 3.73 & 10.22 \\
AUC & 0.78 & 0.51 & 0.69 & 0.71 & 0.67
\end{tabular}

TIC, time-intensity curve; PPV, positive predictive value; NPV, negative predictive value; posLHR, positive likelihood ratio; negLHR, negative likelihood ratio; OR, odds ratio; AUC, area under curve

$61 \%$ and accuracy $77 \%$, and presented with a high diagnostic odds ratio (DOR) 25.14, approving that lack of a rim sign may be used as a criterion of malignant tumour. The other three parameters were characteristic for malignant nodules with likelihood of malignant tumor with DOR from 3.73-6.18, and showed potential in diagnostic testing to differentiate between malignant and benign thyroid mass lesions. The overall pooled sensitivity of selected diagnostic parameters was $82 \%$, specificity $57 \%$, accuracy $70 \%$, and area under curve 0.67 .

ROC analysis revealed that the rim pattern was characterized by high diagnostic performance reflected by AUC 0.78 ( $p=0.01$; CI $0.59-0.93)$. The other parameters possessed lower diagnostic accuracy: wash-out AUC $0.71(p=0.03$; CI 0.56-0.87), TIC curve type AUC $0.69(p=0.05$; CI $0.45-0.88)$ and hypo (iso) vascularity AUC 0.51 ( $p=0.87$; CI $0.30-0.73)$, see Fig. 1.

Heterogeneous enhancement was seen in both types of nodules, showing good sensitivity but very low specificity, $88 \%$ and $34 \%$, respectively, with accuracy of $62 \%$, positive predictive value 0.56 and negative predictive value 0.78 , lacking statistically significant differences between groups ( $p=$ $0.08)$.

Quantitative analysis of TIC curves showed longer halftime wash-out in malignant nodules compared to benign ones with statistical significance, 23.4 and $18.5 \mathrm{~s}$, respectively ( $p=0.048)$. Other parameters, e.g. time to peak (TTP), peak intensity, wash-in slope, mean transit time (MTT) did not show statistically significant difference between malignant and benign nodules $(p>0.05)$.

\section{DISCUSSION}

CEUS is a recently established imaging method allowing to assess tumour vascularisation. The first reports on the use of US contrast medium in assessment of thyroid nodules were 


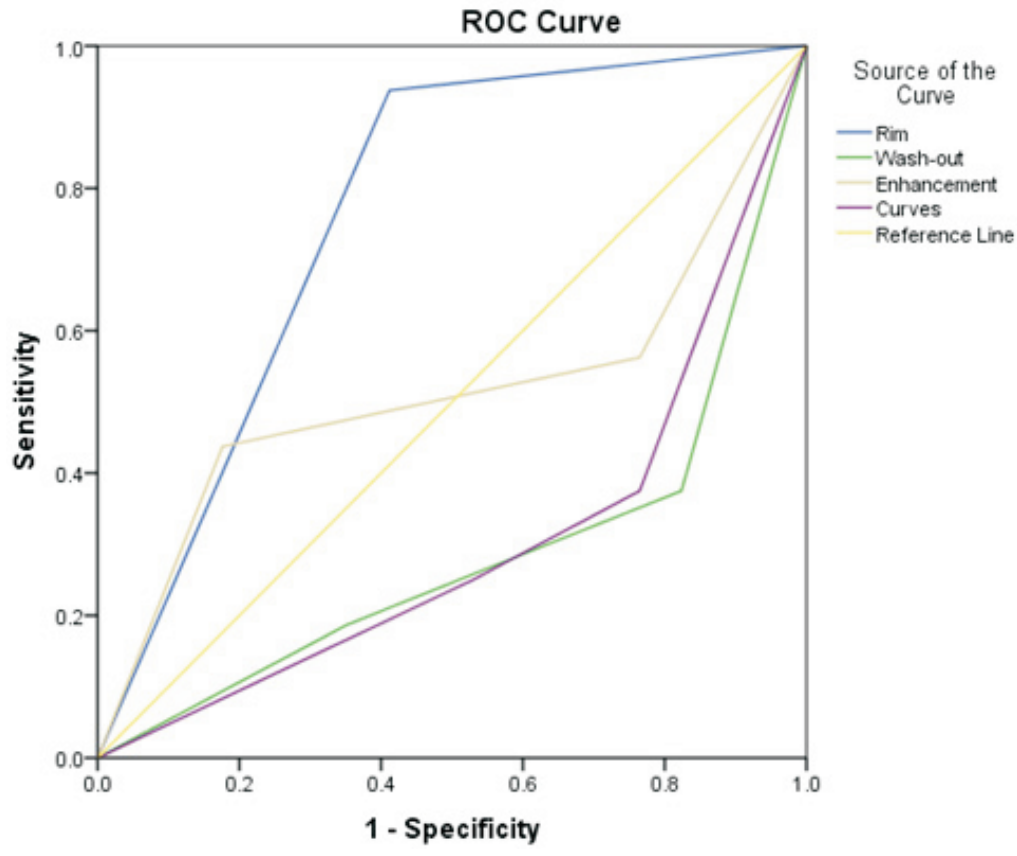

Fig. 1. ROC curves show high sensitivity for rim enhancement (blue line) and high specificity and sensitivity for wash-out (green line) and time-intensity curve (red line) patterns.

presented at the beginning of the last decade (Spiezia et al., 2001; Argalia et al., 2002). However, the number of studies on this topic is still low. The parameters used by the authors in assessment of thyroid nodules differ among studies resulting in complicated comparison of these studies. The results are ambiguous and sometimes even contradictory. For characterisation of nodules both qualitative, e.g., enhancing pattern, and quantitative parameters, e.g., numerical ratings of TIC, have been used. To the best of our knowledge, the diagnostic value of yielded data has been analysed only in a few studies. TIC parameters of shape have been assessed by Ferrari et al., 2008; Nemec et al., 2012 and Giusti et al., 2013. Ferrari et al. (2008) found that in malignant thyroid nodules wash-in and peak-enhancement occurred significantly faster than in benign mass lesions, whereas Nemec et al. (2012), Friedrich-Rust et al. (2010), and Giusti et al. (2013) did not find a significant difference between the malign and benign nodules. In the Nemec's study, the relative intensity of the contrast enhancement was calculated rating the maximum enhancement against the base enhancement, with $84.4 \%$ sensitivity, $76.9 \%$ specificity and $82.6 \%$ diagnostic accuracy (Nemec et al., 2012). In our study, the numerical parameters of TIC did not disclose a difference between malignant and benign nodules.

Ferrari et al. assessed the shape of TIC and reported that it was polyphasic in malignant tumours whereas in benign nodules it was monophasic, with $100 \%$ sensitivity, $71 \%$ specificity, 69\% PPV, 100\% NPV and 83\% accuracy (Ferrari et al., 2008). The shape of the TIC was evaluated also in the early Spiezia's study (Spiezia et al., 2001) using Levovist (Schering, Germany). The authors found that malignant nodules presented slow and polyphasic wash-out, whereas benign nodules showed rapid and regular wash-out (Spiezia et al., 2001). In contrast, the results presented by Argalia et al., in 2002, showed that malignant nodules showed rapid and polyphasic wash-out curve type, while in benign nodules it was rapid and monophasic (Argalia et al.,

2002). In our study, TIC of the slow wash-out type was characteristic of malignant nodules; the sensitivity, specificity and accuracy were $69 \%, 73 \%$, and $71 \%$, respectively. Decelerated and uneven wash-out of the contrast medium from malignant nodules can be explained with functional inefficiency of blood vessels caused by intra-tumoural neoangiogenesis as well as with thrombotic, desmoplastic, and occasionally necrotic processes in nodules.

A relatively greater number of studies have focused on the analysis of contrast enhancement pattern. According to our data, the most reliable symptom of benignity was the rim-like enhancement presenting 94\% sensitivity, $61 \%$ specificity, and $77 \%$ accuracy. In accordance with our results, also in studies by Zhang et al. (2010), Cantisani et al. (2013) and Ma et al. (2014) rim-like enhancement is specific to benign nodules. Results yielded by Zhang et al. (2010) showed $94.1 \%$ specificity, $83.0 \%$ sensitivity. and $88.5 \%$ accuracy. Cantisani et al. evaluated this finding in conjunction with other features and concluded that the specificity of CEUS in detecting of malignant nodules was $91 \%$ and sensitivity - 79\% (Cantisani et al., 2013).

In our study benign nodules showed more intense enhancement in comparison to the surrounding tissue, while for malignant nodules it was similar or weaker; nevertheless, the diagnostic value of this symptom was lower (sensitivity, specificity and accuracy was $82 \%, 56 \%$ and $69 \%$, respectively) due to the small size of the sample. In a recent study by Yuan et al. a higher value of this sign was observed, as shown by $78 \%$ sensitivity and $95 \%$ specificity (Yuan et al., 2015). Deng et al. also used this feature with similar sensitivity and specificity: $82 \%$ and $85 \%$, respectively (Deng et al., 2014).

In our study rapid wash-out of the contrast medium compared to the surrounding tissues in benign nodules was more common than in malignant ones, i.e., $44.4 \%$ to $17.6 \%$ $(p=0.029)$. However, due to the low specificity the practical use of this sign is debatable. 
As we know, so far only one meta-analysis on study results regarding CEUS has been done. Yu et al. collected results from seven publications; in three of them quantitative parameters were used but in four - the qualitative parameters (Yu et al., 2014). The pooled sensitivity of differentiation between benign and malignant nodules was $85.3 \%$, the specificity $-87.6 \%$, PPV -5.822 , and NPV -0.195 . The value of qualitative and quantitative parameters did not show significant difference. The authors, however, emphasised that the assessment was impacted by the small number of studies and different evaluation parameters, especially, regarding the qualitative evaluation.

\section{CONCLUSIONS}

Our results confirm CEUS as a potentially valuable non-invasive imaging method in differential diagnosis of thyroid nodules, which can significantly supply conventional US and FNAB. However, extensive further research is needed to develop a unified technology and approach for data evaluation.

\section{ACKNOWLEDGMENTS}

The present work was carried out within the frames of the scientific project No. 2013/0004/1DP/1.1.1.2.0/13/APIA/ VIAA/020, supported by the European Social Fund (ESF).

\section{REFERENCES}

Anonymous (2007). British Thyroid Association, Royal College of Physicians. Guidelines for the Management of Thyroid Cancer. $2^{\text {nd }}$ edition. London: Royal College of Physicians. 106 pp.

Argalia, G., De Bernardis, S., Mariani, D., Abbattista, T., Taccaliti, A., Ricciardelli, L., Faragona, S., Gusella, P. M., Giuseppetti, G. M. (2002). Ultrasonographic contrast agent: Evaluation of time-intensity curves in the characterization of solitary thyroid nodules. Radiol. Med., 103 (4), 407-413.

Cantisani, V., Consorti, F., Guerrisi, A., Guerrisi, I., Ricci, P., Di Segni, M., Mancuso, E., Scardella, L., Milazzo, F., D’Ambrosio, F., Antonaci, A (2013). Prospective comparative evaluation of quantitative-elastography (Q-elastography) and contrast-enhanced ultrasound for the evaluation of thyroid nodules: preliminary experience. Eur. J. Radiol., 82 (11), 1892-1898.

Chow, L. S., Gharib, H., Goellner, J. R., van Heerden, J. A. (2001). Nondiagnostic thyroid fine-needle aspiration cytology: Management dilemmas. Thyroid, 11 (12), 1147-1151.

Cibas, E. S., Ali, S. Z., NCI Thyroid FNA State of the Science Conference. (2009). The Bethesda system for reporting thyroid cytopathology. Amer. J. Clin. Pathol., 132 (5), 658?665.

Deng, J., Zhou, P., Tian, S.M., Zhang, L., Li, J. L., Qian, Y. (2014). Comparison of diagnostic efficacy of contrast-enhanced ultrasound, acoustic radiation force impulse imaging and their combined use in differentiating focal solid thyroid nodules. PLoS One, 9 (3). DOI: 10.1371/journal.pone.0090674.

Ferlay, J., Steliarova-Foucher, E., Lortet-Tieulent, J., Rosso, S., Coebergh, J. W., Comber, H., Forman, D., Bray, F. (2013). Cancer incidence and mortality patterns in Europe: Estimates for 40 countries in 2012. Eur. J. Cancer, 49 (6), 1374-1403.
Ferrari, F. S., Megliola, A., Scorzelli, A., Guarino, E., Pacini, F. (2008). Ultrasound examination using contrast agent and elastosonography in the evaluation of single thyroid nodules: Preliminary results. J. Ultrasound, 11 (2), 47-54.

Friedrich-Rust, M., Sperber, A., Holzer, K., Diener, J., Grünwald, F., Badenhoop, K., Weber, S., Kriener, S., Herrmann, E., Bechstein, W. O., Zeuzem, S., Bojunga, J. (2010). Real-time elastography and contrast-enhanced ultrasound for the assessment of thyroid nodules. Exp. Clin. Endocrinol. Diabetes, 118 (9), 603-609.

Gharib, H., Papini, E., Paschke, R., Duick, D. S., Valcavi, R., Hegedüs, L., Vitti, P. (2010). American Association of Clinical Endocrinologists, Associazione Medici Endocrinologi, and European Thyroid Association medical guidelines for clinical practice for the diagnosis and management of thyroid nodules. Endocrine Practice, 16 (1), 1-43.

Giusti, M., Orlandi, D., Melle, G., Massa, B., Silvestri, E., Minuto, F., Turtulici, G. (2013). Is there a real diagnostic impact of elastography and contrast-enhanced ultrasonography in the management of thyroid nodules? J. Zhejiang Univ. Sci. B, 14 (3), 195-206.

Ma, J. J., Ding, H., Xu, B. H., Xu, C., Song, L. J., Huang, B. J., Wang, W. P. (2014). Diagnostic performances of various gray-scale, color Doppler, and contrast-enhanced ultrasonography findings in predicting malignant thyroid nodules. Thyroid, 24 (2), 355-356.

Nemec, U., Nemec, S.F., Novotny, C., Weber, M., Czerny, C., Krestan, C. R. (2012). Quantitative evaluation of contrast-enhanced ultrasound after intravenous administration of a microbubble contrast agent for differentiation of benign and malignant thyroid nodules: Assessment of diagnostic accuracy. Eur. Radiol., 22 (6), 1357-1365.

Orija, I. B., Pineyro, M., Biscotti, C., Reddy, S. S., Hamrahian, A. H. (2007). Value of repeating a nondiagnostic thyroid fine-needle aspiration biopsy. Endocr. Pract., 13 (7), 735-742.

Piscaglia, F., Nolsøe, C., Dietrich, C. F., Cosgrove, D. O., Gilja, O. H., Bachmann Nielsen, M., Albrecht, T., Barozzi, L., Bertolotto, M., Catalano, O., Claudon, M., Clevert, D. A, Correas, J. M., D’Onofrio, M., Drudi, F. M., Eyding, J., Giovannini, M., Hocke, M., Ignee, A., Jung, E. M., Klauser A. S., Lassau N., Leen E., Mathis, G., Saftoiu, A., Seidel, G., Sidhu P. S., ter Haar G., Timmerman D., Weskott, H. P. (2012). The EFSUMB Guidelines and Recommendations on the Clinical Practice of Contrast Enhanced Ultrasound (CEUS): Update 2011 on non-hepatic applications. Ultraschall Med., 33 (1), 33-59.

Replogle, W.H., Johnson, W.D., Hoover, K.W. (2009). Using evidence to determine diagnostic test efficacy. Worldviews Evid. Based Nurs., 6 (2), 87-92.

Samir, A. E., Vij, A., Seale, M. K., Desai, G., Halpern, E., Faquin, W. C., Parangi. S., Hahn, P. F., Daniels, G. H. (2012). Ultrasound-guided percutaneous thyroid nodule core biopsy: Clinical utility in patients with prior nondiagnostic fine-needle aspirate. Thyroid, 22 (5), 461-467.

Spiezia, S., Farina, R., Cerbone, G., Assanti, A. P., Iovino, V., Siciliani, M., Lombardi, G., Colao, A. (2001). Analysis of color Doppler signal intensity variation after levovist injection: A new approach to the diagnosis of thyroid nodules. J. Ultrasound Med., 20 (3), 223-231.

Strauss, E. B., Iovino, A., Upender, S. (2008). Simultaneous fine-needle aspiration and core biopsy of thyroid nodules and other superficial head and neck masses using sonographic guidance. Amer. J. Roentg., 190 (6), 1696-1699.

Yu, D., Han, Y., Chen, T. (2014). Contrast-enhanced ultrasound for differentiation of benign and malignant thyroid lesions: meta-analysis. Otolaryngol. Head Neck Surg., 151 (6), 909-915.

Yuan, Z., Quan, J., Yunxiao, Z., Jian, C., Zhu, H. (2015). Contrast-enhanced ultrasound in the diagnosis of solitary thyroid nodules. J. Cancer Res. Ther., 11 (1), 41-45.

Zhang, B., Jiang, Y. X., Liu, J. B., Yang, M., Dai, Q., Zhu, Q. L., Gao, P. (2010). Utility of contrast-enhanced ultrasound for evaluation of thyroid nodules. Thyroid, 20 (1), 51-57. 


\section{KONTRASTA ULTRASONOGRĀFIJAS DIAGNOSTISKĀ PRECIZITĀTE LABDABĪGU UN L,AUNDABĪGU SOLITĀRU VAIROGDZIEDZERA MEZGLU DIFERENCIĀLDIAGNOSTIKĀ}

Pētījuma mērḳis bija noteikt kontrasta ultrasonogrāfijas diagnostisko precizitāti labdabīgu un ḷaundabīgu vairogdziedzera mezglu diferenciāldiagnostikā. Pētījumā tika iekḷauti 35 pacienti ar morfoloğiski pierādītiem solitāriem vairogdziedzera mezgliem (17 ḷaundabīgi un 18 labdabīgi veidojumi), kuriem veikta ultrasonogrāfija ar kontrastvielu un novērtētas sekojošas kontrastēšanās veida pazīmes: vaskularizācijas relatīvā pakāpe, kontrastēšanās homogenitāte, perifērā jeb gredzenveida kontrastēšanās, kontrastvielas izvades relatīvais ātrums un vaskularizācijas relatīvā pakāpe, lietojot kumulācijas programmu. Pēcapstrādē tika novērtēts kontrastēšanās intensitātes maiṇas līknes (KIL) veids (lēna, ātra un stabila, ātra un divfāziska). Šis pazīmes tika salīdzinātas ar mezgla morfoloğisko veidu, un noteikti diagnostiskās precizitātes lielumi. Konstatēta vidēji cieša korelācija starp mezgla morfoloğisko dabu un KIL veidu $\mathrm{r}_{\mathrm{s}}=0,38(p=0,021)$, kā arī vaskularizācijas relatīvo pakāpi $\mathrm{r}_{\mathrm{s}}=0,39(p=0,022)$ un kontrastvielas izvades relatīvo ātrumu $\mathrm{r}_{\mathrm{s}}=0,39(p=0,024)$. Summārā izvēlēto diagnostisko pazīmju jutība bija $82 \%$, specifiskums $57 \%$ un precizitāte $70 \%$. L,aundabīgiem audzējiem bija raksturīgs hipo- vai izovaskulārs kontrastēšanās veids un lēns relatīvais kontrastvielas izvades ātrums, savukārt labdabīgiem mezgliem tipiska bija gredzenveida kontrastēšanās un divfāzisks, ātrs KIL veids. Secināts, ka ḷaundabīgu un labdabīgu vairogdziedzera mezglu ultrasonogrāfiskās kontrastēšanās veids būtiski atšķiras. Ultrasonogrāfijas kontrastizmeklējums ir pielietojams kā vairogdziedzera mezglu izmeklēšanas papildus metode ar augstu diagnostisku precizitāti. 